\title{
A new method using fluorescent microspheres to determine grazing on ciliates by the mixotrophic dinoflagellate Ceratium furca
}

\author{
Gabriela W. Smalley ${ }^{1,2, *}$, D. Wayne Coats ${ }^{1}$, E. Jeremy Adam ${ }^{1}$ \\ ${ }^{1}$ Smithsonian Environmental Research Center, PO Box 28, Edgewater, Maryland 21037, USA \\ ${ }^{2}$ University of Maryland System, Center for Environmental Studies, Horn Point Laboratory, Cambridge, Maryland 21613, USA
}

\begin{abstract}
Feeding in the mixotrophic dinoflagellate Ceratium furca was investigated using $1 \mu \mathrm{m}$ fluorescent microspheres to label prey. Microspheres added to natural plankton assemblages at a concentration of $5 \times 10^{6}$ to $10^{7} \mathrm{ml}^{-1}$ were rapidly ingested by a variety of planktonic organisms including small flagellates, ciliates, dinoflagellates, ebriids and amoebae. Prey thus labeled were in turn phagocytized by $C$. furca and were easily detected within the predator using fluorescent microscopy. Ingestion rates were calculated by following the appearance of labeled food vacuoles in $C$. furca over time. $C$. furca did not ingest microspheres directly, and thus the calculated rates represented feeding on labeled prey only. Food vacuole contents and labeled prey were identified using a modified Protargol staining procedure that retained the integrity and fluorescent properties of the latex microspheres. Data on food vacuole content and potential prey availability indicated that $C$. furca preyed mainly on choreotrich ciliates (i.e. Strobilidium spp. and tintinnids) 10 to $40 \mu \mathrm{m}$ in diameter. In addition, feeding rates were strongly correlated with choreotrich densities and suggested that $C$. furca preferred ciliates of the genus Strobilidium. Ingestion rates of $C$. furca ranged from 0 to $0.11 \mathrm{prey} \mathrm{h}^{-1}$, and varied greatly from one year to the next. Clearance rates ranged from 0 to $12.49 \mu \mathrm{l}(\mathrm{C} \text {. furca })^{-1} \mathrm{~h}^{-1}$, with an average of $2.1 \pm 0.41 \mathrm{ml}(\mathrm{C}$. furca $)^{-1} h^{-1}$ Both ingestion and clearance rates were comparable to rates previously reported for mixotrophic and heterotrophic dinoflagellates. The method presented here has several advantages for the study of mixotrophy in large, slow-feeding dinoflagellates. Live prey found in natural water samples are used, and surface characteristics of prey remain unaltered. No addition of prey is necessary, and only a minimum amount of handling of the sample is required. Incubation experiments can last for $6 \mathrm{~h}$, allowing sufficient time for the appearance of labeled food vacuoles in predators with low feeding rates.
\end{abstract}

KEY WORDS: Ceratium furca - Mixotrophy - Dinoflagellates - Ciliates - Fluorescent microspheres · Chesapeake Bay

\section{INTRODUCTION}

Mixotrophic protozoa gain their nutrition through a combination of photosynthesis and uptake of dissolved or particulate organic material. They vary widely in their photosynthetic and phagotrophic capabilities, and may be regarded as occupying different points along a spectrum of nutritional strategies that range between pure autotrophy and pure heterotrophy (Sanders 1991, Jones 1994). These nutritional strate-

•E-mail: smalley@serc.si.edu gies may give mixotrophs a competitive advantage over strict phototrophs, since phagotrophy could enable them to acquire carbon and nutrients when photosynthesis is limited (Sanders et al. 1990, Sanders 1991, Bockstahler \& Coats 1993a, Nygaard \& Tobiesen 1993). Conversely, mixotrophs may outcompete strict heterotrophs by fixing carbon to survive periods of reduced particulate food availability (Andersson et al. 1989, Sanders et al. 1990, Rothhaupt 1996). Despite increasing reports of mixotrophy in a variety of protists, the benefits and ecological advantages of this nutritional strategy remain largely speculative. 
Mixotrophy is common among photosynthetic dinoflagellates and appears particularly well developed in species of Ceratium (Schnepf \& Elbrächter 1992). For example, Dodge \& Crawford (1970) reported food vacuoles in $C$. hirundinella that contained bacteria, bluegreen algae, and diatoms. Similarly, Hofender (1930) observed $C$. hirundinella feeding on a variety of prey including cyanobacteria, diatoms, and ciliates, and noted phagotrophy by C. furca, C. tripos, and C. cornutum. Predation on ciliates has also been demonstrated for C. furca (Bockstahler \& Coats 1993a, Li et al. 1996) and C. longipes (Jacobson \& Anderson 1996), and food vacuoles containing unidentified prey have been found in C. Lunula, $C$. teres, $C$. declinatum f. normale, $C$. furca, and C. fusus (Norris 1969, Cachon et al. 1991, Chang \& Carpenter 1994). While some of these studies have quantified the prevalence of food vacuoles in field populations (Bockstahler \& Coats 1993a, Chang \& Carpenter 1994, Li et al. 1996), none have determined feeding rates for Ceratium species in culture or in the field.

This lack of data on feeding rates might be partly due to difficulties in selecting an appropriate method to investigate feeding in large mixotrophic dinoflagellates like those of the genus Ceratium. Methods frequently used to study feeding behavior and ingestion rates of planktonic protists employ a variety of tracers such as fluorescently labeled, heat-killed bacteria and algae, fluorescent microspheres, and paint, dye, or starch particles (McManus \& Fuhrman 1985, Bird \& Kalff 1987, Sherr et al. 1987, Rublee \& Gallegos 1989, Sherr et al. 1991). However, not all protists will ingest inert surrogate prey (Stoecker 1988, Jones et al. 1993, Cleven 1996), and phagotrophy may consequently go undetected or be underestimated in certain taxa. A variety of radioisotope labeling techniques that use live prey labeled with ${ }^{14} \mathrm{C}$ have also been developed (Nygaard \& Hessen 1990). However, these approaches are restricted to short-term incubations and require a large amount of handling when prefiltering, incubating, washing and fractionating prey, procedures that may disturb or alter the natural prey assemblages (Landry 1994). Recently, Li et al. (1996) used live prey, including phycoerythrin-containing cryptophytes that exhibit distinct yellow-orange autofluorescence and protists stained with CMFDA (5-chIoromethylfluorescein diacetate), a low-toxic, vital stain with green fluorescence, to qualitatively demonstrate feeding in several mixotrophic dinoflagellates. Unfortunately, none of these tracer techniques are ideal for measuring ingestion in large mixotrophic dinoflagellates that typically feed at very low rates. To quantify ingestion rates in species like C. furca, Gyrodinium uncatenum, and Gymnodinium sanguineum, within time constraints imposed by digestive processes, would require addition of higher than 'tracer' concentrations of labeled prey, thus altering the original composition of the natural plankton assemblage.

Ingestion rates for various protists have also been estimated using a 'gut clearance/gut fullness' approach (Kopylov \& Tumantseva 1987, Dolan \& Coats 1991a, Bockstahler \& Coats 1993b). In this approach, digestion rates determined by following the disappearance of phagocytized prey over time are used in conjunction with data on 'gut content' of specimens collected from the field or from laboratory cultures to estimate ingestion rate. Bockstahler \& Coats (1993b) used this method to quantify feeding by Gymnodinium sanguineum and estimate its impact on ciliate prey populations in Chesapeake Bay. This approach is attractive as no handling or incubation of the dinoflagellate is needed to estimate ingestion rates; however, it is very labor-intensive, and several assumptions are required. For example, digestion rate must be independent of 'gut content', and ingestion and digestion must be in equilibrium (i.e. steady-state conditions).

Dolan \& Coats (1991b) developed a technique using bacteria-sized fluorescent microspheres to demonstrate feeding in a variety of predacious ciliates in the laboratory. Microspheres added to ciliate cultures at a concentration of $10^{7} \mathrm{ml}^{-1}$ were readily ingested by a number of bactivorous species, which yielded motile, labeled prey with presumably unaltered surface characteristics. Prey ciliates so labeled were ingested by larger ciliates and could be detected using fluorescence microscopy. In the present study, we modified this method for use in the field to determine food vacuole contents and feeding rates of Ceratium furca, a large mixotrophic dinoflagellate which periodically forms summer blooms in surface waters of Chesapeake Bay (Mulford 1963, Marshall 1980, Bockstahler \& Coats 1993a). When we added fluorescent microspheres to natural plankton assemblages that contained C. furca, microspheres were ingested by a variety of planktonic organisms, some of which were in turn ingested by $C$. furca. Food vacuoles containing labeled prey were easily located within $C$. furca using fluorescent microscopy, and could be distinguished from previously ingested, unlabeled prey. With this method, we were able to demonstrate mixotrophy in $C$. furca, determine food vacuole contents and prey preferences, and quantify ingestion rates on labeled prey.

\section{MATERIALS AND METHODS}

All experiments were conducted aboard the RV 'Cape Henlopen' on Chesapeake Bay, USA, during the summer of 1995 and 1996. Natural water samples were collected along the main axis of Chesapeake Bay, and treatments were incubated in polycarbonate sample 
bottles in a flowing seawater bath on deck. The water bath was covered with a screen that reduced the incoming light intensity by approximately $65 \%$ to simulate natural light levels at 1.5 to $2 \mathrm{~m}$ depth. All treatments were incubated during the day, unless otherwise indicated. Samples were preserved in modified Bouin's fixative immediately after withdrawal (Coats \& Heinbokel 1982).

Enumeration and identification of Ceratium furca and its prey. Ceratium furca densities and number of food vacuoles per $C$. furca cell were determined by placing each sample in a Zeiss settling chamber (5 to $50 \mathrm{ml}$, depending on $C$. furca densities). After allowing the cells to settle, the entire chamber was scanned at $\times 200$ to $\times 400$ on an inverted microscope equipped with epifluorescence (Leitz Diavert, HBO 100 W/2 mercury lamp), and the number of labeled food vacuoles per cell was recorded for the first 100 specimens encountered. For the time-course feeding experiment, ingestion rate was determined as the slope for the linear regression of number of food vacuoles per C. furca plotted against time, using the initial linear part of the feeding curve (SigmaStat Version 2.0, Jandel Scientific Software). To assess feeding in natural populations, ingestion rates were calculated by dividing the number of food vacuoles per $C$. furca at the end of the incubation by total incubation time. Clearance rates were calculated from ingestion rates and Strobilidium spp. abundance, assuming feeding on Strobilidium spp. only.

To enumerate and identify potential prey, and to identify food vacuole contents of Ceratium furca, 15 or $20 \mathrm{ml}$ quantitative Protargol stain (QPS) preparations (Montagnes \& Lynn 1987) were made from all samples fixed after $1 \mathrm{~h}$ of incubation. The remaining samples of the prey-labeling experiment and the whole-water treatment of the time-course feeding experiment were also stained. In the QPS procedure, the sample is concentrated on a filter, which is then stained, dehydrated, cleared in xylene, and mounted on a microscope slide. However, because xylene dissolves latex microspheres, we avoided dehydration and xylene clearing by using a water-soluble mounting medium (Plastic mount mounting media, Polysciences, Inc., Warrington, PA). Protargol-stained filters were soaked in the mounting medium tor 1 to 2 min, placed on a microscope slide and capped with a cover slip. After the filters had become transparent (approximately $1 \mathrm{~h}$ ), the slides were placed under UV light for $5 \mathrm{~h}$ until the medium hardened. Exposure to UV light did not markedly decrease microsphere fluorescence.

Potential prey were counted, measured using a calibrated ocular micrometer, and categorized into major taxonomic groups, with ciliates identified to genus. Flagellate density was estimated by enumerating specimens present in arbitrarily selected microscope fields until $>100$ individuals were counted. For all other groups, an equivalent of 1 to $4 \mathrm{ml}$ whole-water sample was analyzed $(\times 1000$, Zeiss Axioscope equipped with fluorescence). The number of microspheres ingested by each specimen was determined for samples of the time-course feeding experiment.

Labeling prey. To determine the microsphere concentration that optimized labeling of prey, surface water containing a variety of ciliates and small dinoflagellates was collected from $37^{\circ} 47^{\prime} \mathrm{N}, 76^{\circ} 11^{\prime} \mathrm{W}$ on 8 July 1996 and distributed into ten $500 \mathrm{ml}$ polycarbonate bottles. Fluorescent latex microspheres (Fluoresbrite plain YG 1.0 micron; Polysciences, Inc., Warrington, PA) were added to duplicate bottles at $5 \times 10^{5} \mathrm{ml}^{-1}$, $10^{6} \mathrm{ml}^{-1}, 5 \times 10^{6} \mathrm{ml}^{-1}$, and $10^{7} \mathrm{ml}^{-1}$. Because ingestion of microspheres by prey could lead to a decrease in prey density over time due to starvation, 1 set of duplicate bottles without addition of microspheres served as a control. All treatments were incubated for $6 \mathrm{~h}$, with $20 \mathrm{ml}$ aliquots removed from each bottle and fixed immediately after 1, 15, 30, 60, and $360 \mathrm{~min}$.

Linear regression was used to calculate net growth rates of the ciliates at different microsphere concentrations over the $6 \mathrm{~h}$ period (SigmaStat). Rates were compared for significant differences using SAS/MIXED procedures (SAS 1996). The criteria used to select the optimum microsphere concentration for subsequent experiments were: (1) quick uptake of microspheres by prey of Ceratium furca, (2) uptake of the most microspheres by prey, and (3) no decrease in prey density over the course of the experiment.

Feeding of Ceratium furca on prey labeled with fluorescent microspheres. Time-course feeding experiment: The suitability of prey labeled with microspheres as a means for obtaining feeding rates and prey preferences of Ceratium furca was tested in a time-course feeding experiment. The experiment consisted of 3 treatments: (1) unscreened whole water, (2) 'prey-free' control, and (3) 'disturbed' control. A natural plankton assemblage containing $C$. furca was collected from surface waters at $38^{\circ} 18^{\prime} \mathrm{N}, 76^{\circ} 17^{\prime} \mathrm{W}$ on 22 August 1995. Three liters of unscreened plankton sample were distributed into triplicate 11 polycarbonate bottles for the whole-water treatment, and fluorescent latex microspheres were added at a concentration of $10^{7} \mathrm{ml}^{-1}$. The ability of $C$. furca to ingest microspheres directly was examined in the 'prey-free' control. For this control, C. furca were washed free of prey by repeated reverse filtration using 15 to $20 \mu \mathrm{m}$ Nitex mesh. In this process, $4 \mathrm{l}$ of whole-water sample were gently reduced to $\sim 100 \mathrm{ml}$ and then returned to $1 \mathrm{l}$ using Gelman A/E filtered estuarine water. The dinoflagellates were subjected to 3 similar additional washes, and then brought to 21 with filtered water. The whole process took between 30 and $45 \mathrm{~min}$ and 
yielded a viable $C$. furca population of approximately the same cell density as the original sample. Because the process of reverse filtration, rather than the absence of prey, could have prevented C. furca from feeding in the 'prey-free' control, we added a second control. For this 'disturbed' control, $100 \mathrm{ml}$ of concentrated C. furca washed free of prey as above were combined with $1900 \mathrm{ml}$ of prey from the initial filtrate of the reverse filtration process to produce a plankton population similar to the original assemblage. The samples for both 'prey-free' and 'disturbed' controls were distributed into duplicate $1 \mathrm{l}$ polycarbonate bottles, and microspheres were added at the same concentration as above. All treatments were incubated for approximately $12 \mathrm{~h}$, starting at 13:00 $\mathrm{h}$ and lasting until $00: 30 \mathrm{~h}$. Aliquots were removed after 1, 30,60, 100, $150,240,330,450$, and $690 \mathrm{~min}$ of incubation and immediately preserved. The density of $C$. furca in all 3 treatments was analyzed for significant changes over the course of the experiment, and ingestion rates obtained for the 3 treatments were compared for significant differences (SAS/MIXED procedures).

In addition, the number of labeled food vacuoles per Ceratium furca was determined with settled counts in four $20 \mathrm{ml}$ subsamples fixed after $330 \mathrm{~min}$ of incubation. These same samples were subsequently stained with Protargol and examined at $\times 1000$ (Zeiss Axioscope). The number of labeled food vacuoles per $C$. furca obtained by this method was compared to that of the settled counts using 1-way analysis of variance (ANOVA; SigmaStat).

Characteristics of food vacuole contents and potential prey. To determine food vacuole contents of Ceratium furca, QPS preparations of the whole-water treatment were examined sequentially by sampling time beginning at $T_{0}$, until 200 labeled $C$. furca food vacuoles were encountered (Zeiss Axioscope, $\times 1000$ ). Food vacuole contents were cataloged as ciliates, non-ciliates, or nonrecognizable food items, using criteria such as nuclear morphology and presence of somatic or oral ciliature. Recognizable ciliates contained in vacuoles were further distinguished at the subclass to genus level. Food vacuole size ([width + length]/2) was measured with a calibrated ocular micrometer and used to determine the size range of potential prey. The number of microspheres per food vacuole was also recorded. Median sizes of food vacuoles containing various quantities of ingested microspheres were compared for significant differences (Kruskal-Wallis 1-way ANOVA on Ranks; SigmaStat). In addition, the median size of food vacuoles containing fewer than 10 microspheres was compared to that of food vacuoles with recognizable ciliate contents (Mann-Whitney Rank Sum Test; SigmaStat).

Assessment of feeding in natural populations of $\mathbf{C e r}$ atium furca. During June through September of 1995, and July through September of 1996, we conducted 30 feeding experiments using prey labeled with fluorescent microspheres to test the applicability of our method to the study of feeding in natural Ceratium furca assemblages. Whole water that contained $C$. furca was collected at various stations and depths throughout the meso- and polyhaline portion of Chesapeake Bay. Microspheres were added at a concentration of $5 \times 10^{6}$ to $10^{7} \mathrm{ml}^{-1}$, and the water was incubated in polycarbonate bottles $(250 \mathrm{ml}$ to $2 \mathrm{l}$ bottles, depending on C. furca density). After 1 h of incubation, a $20 \mathrm{ml}$ aliquot was withdrawn and preserved for subsequent Protargol staining. After approximately $6 \mathrm{~h}, 100 \mathrm{ml}$ to 21 (depending on C. furca density) of the sample were fixed for analysis by inverted epifluorescent microscopy. Ciliate abundance and ingestion and clearance rates for C. furca were determined. Comparison of ingestion rate with potential prey density was made using Pearson Product Moment Correlation (SigmaStat).

\section{RESULTS}

A variety of planktonic groups ingested fluorescent microspheres, including small flagellates, ciliates, dinoflagellates, ebriids and amoebae. Labeled prey, especially choreotrich ciliates (Figs. $1 \& 2$ ), were in turn

Figs. 1 to 5. Strobilidium spp. and Ceratium furca labeled with fluorescent microspheres. Figs. 1 \& 2. labeled specimens of Strobilidium spp. abundant in Chesapeake Bay and common prey of C. furca. Bar $=10 \mu \mathrm{m}$. Fig. 1. Strobilidium spp., stained using modified Protargol procedures that do not dissolve latex microspheres, photographed (A) without and $(B)$ with epifluorescence illumination. FM: fluorescent microspheres; M: macronucleus; OC: oral cilia. Fig. 2. Strobilidium spp. containing fluorescent microspheres (FM). Specimen was fixed with Bouin's preservative and viewed under epifluorescent illumination. Figs. 3 to 5. Food vacuoles of C. furca. Bar $=10 \mu \mathrm{m}$. Fig. 3. C. furca containing a food vacuole with labeled prey (arrow), fixed with Bouin's preservative and viewed under epifluorescent illumination. Fig. 4. Protargol preparation of $C$. furca with a food vacuole containing a recently ingested, small choreotrich ciliate. N: Ceratium nucleus. (A) Macronucleus (M) and oral cilia (OC) of the choreotrich are recognizable. (B) Under epifluorescent illumination, microspheres (arrow) ingested by the choreotrich prey become visible. Fig. 5. Protargol preparation of C. furca with an older, dark food vacuole (FV) and 1 containing a recently ingested, large Strobilidium species labeled with microspheres. N: Ceratium nucleus; Macronucleus (M) and oral cilia (OC) of the ingested Strobilidium sp. are clearly visible. The specimen is viewed (A) without and (B) with epifluorescent illumination. Arrow: fluorescent microspheres ingested by the prey 


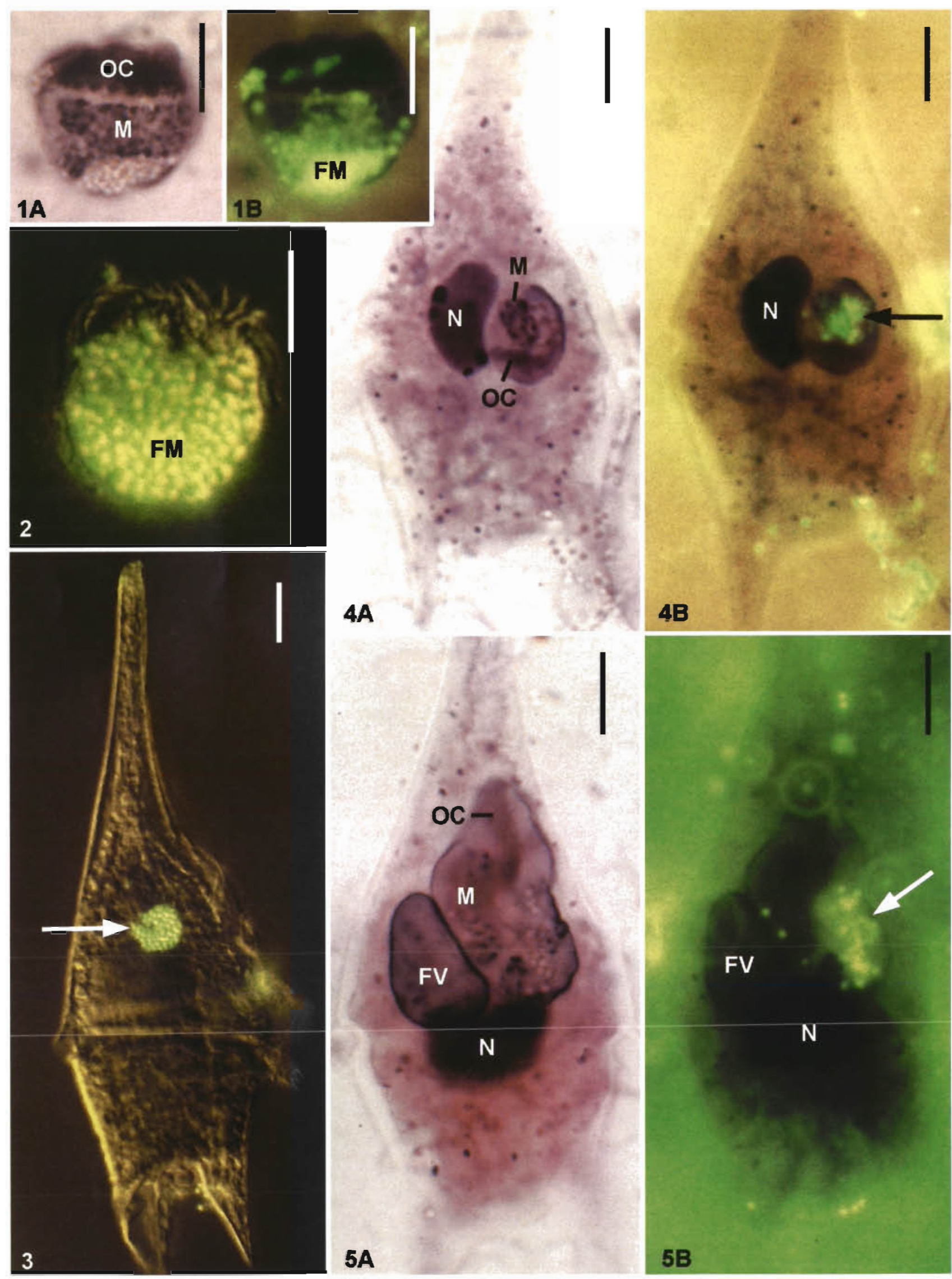


ingested by Ceratium furca. Using inverted epifluorescent microscopy of settled samples, food vacuoles that contained labeled prey were easily located within C. furca (Fig. 3), and could be distinguished from previously ingested, unlabeled prey. When we compared the number of labeled food vacuoles per $C$. furca obtained by epifluorescent microscopy of settled samples with the number determined from Protargol preparations, we found no significant difference $(F=1.841, \mathrm{df}=7, \mathrm{p}=$ 0.224 ; SigmaStat). The use of water-soluble mounting medium slightly decreased the quality of Protargol preparations, but did not inhibit identification of ingested or potential prey. In addition, this technique allowed the detection of microspheres within prey and predator under epifluorescent light (Figs. 4 \& 5).
Table 1 Ciliate net growth rates during incubations at $0,5 \times 10^{5}, 10^{6}$, $5 \times 10^{6}$ and $10^{7}$ microspheres $\mathrm{ml}^{-1}$ Net growth rates were determined as the slope of linear regression for ciliate density plotted against time; $a$ 1 -way ANOVA was performed to check if the rates were significantly different from zero $(p<0.05)$

\begin{tabular}{|lccc|}
\hline $\begin{array}{l}\text { Treatment } \\
\left.\text { (microspheres } \mathrm{ml}^{-1}\right)\end{array}$ & $\begin{array}{c}\text { Net growth rate } \pm \mathrm{SE} \\
\left(\text { ciliates } \mathrm{h}^{-1}\right)\end{array}$ & $F(\mathrm{df}=4)$ & p-value \\
\hline Ciliates: & $2.04 \pm 1.080$ & 3.58 & 0.16 \\
Control $(0)$ & $1.38 \pm 2.460$ & 0.32 & 0.61 \\
$5 \times 10^{5}$ & $1.38 \pm 1.560$ & 0.81 & 0.43 \\
$10^{6}$ & $-0.54 \pm 1.536$ & 0.11 & 0.76 \\
$5 \times 10^{6}$ & $-0.48 \pm 0.306$ & 2.82 & 0.19 \\
$10^{7}$ & & & \\
$\leq 20 \mu \mathrm{m}$ choreotrichs: & $1.92 \pm 0.480$ & 15.54 & 0.03 \\
Control $(0)$ & $0.72 \pm 0.750$ & 0.88 & 0.42 \\
$5 \times 10^{5}$ & $0.54 \pm 0.492$ & 1.24 & 0.35 \\
$10^{6}$ & $0.96 \pm 0.690$ & 1.84 & 0.27 \\
$5 \times 10^{6}$ & $-0.12 \pm 0.534$ & 0.04 & 0.86 \\
$10^{7}$ & & & \\
\hline
\end{tabular}

\section{Labeling prey}

The initial concentration of microspheres added to the natural samples influenced the rate of microsphere ingestion by potential prey. When we added microspheres at a concentration of $5 \times 10^{6}$ or $10^{7} \mathrm{ml}^{-1}, 32.3 \pm$ $0.78 \%$ of total ciliates and $76.8 \pm 1.30 \%$ of small $(\leq 20 \mu \mathrm{m})$ choreotrichs were labeled after $1 \mathrm{~min}$. In contrast, only $8.0 \pm 1.78 \%$ of total ciliates and $20.1 \pm 0.35 \%$ of small choreotrichs were labeled within the same time period when concentrations of $5 \times 10^{5}$ or $10^{6}$ microspheres $\mathrm{ml}^{-1}$ were used. After $15 \mathrm{~min}, 53.8 \pm$ $1.42 \%$ of total ciliates and $95.2 \pm 1.49 \%$ of small choreotrichs were labeled regardless of microsphere concentration. This percentage remained high during the course of the experiment, with $78.0 \pm 2.30 \%$ of total ciliates and $99.4 \pm 0.52 \%$ of small oligotrichs labeled after 6 h. Initial microsphere concentration also influenced the number of microspheres ingested by potential prey. For example, ciliates present in the natural plankton assemblage, on average, contained fewer microspheres per cell at $5 \times 10^{5}$ microspheres $\mathrm{ml}^{-1}$ than at higher concentrations after 60 min of incubation. Only $34.0 \%$ of labeled ciliates ingested 20 or more micrnspheres at the lowest concentration. This percentage increased to $72.7 \%$ at the highest concentration. Similar results were obtained for small choreotrichs (data not shown). With the exception of a slight increase of small choreotrich numbers in the control treatment, ciliate and small choreotrich densities did not change significantly over $6 \mathrm{~h}$ (i.e. no net growth or mortality occurred in the presence of microspheres; Table 1). In addition, the net growth rates of total ciliates and small choreotrichs were not significantly different from those observed in the con- trol, even at the highest microsphere concentration used (total ciliates: $F=0.66$, df $=4, \mathrm{p}=0.62$; small choreotrichs: $F=1.4$, df $=4, \mathrm{p}=0.25$ ).

\section{Feeding of Ceratium furca on prey labeled with fluorescent microspheres}

\section{Time-course feeding experiment}

Abundance of Ceratium furca in the whole-water. 'prey-free', and 'disturbed' treatments was $1.5 \pm 0.01$, $3.6 \pm 0.04$, and $2.3 \pm 0.02 \mathrm{ml}^{-1}$, respectively, and showed no significant change over the course of the experiment. Ciliate abundance in unscreened water was $77.3 \pm 7.15 \mathrm{ml}^{-1}$. Of these, $87.2 \%$ were choreotrich ciliates $\leq 20 \mu \mathrm{m}$ in size. Reverse filtration procedures used to obtain the 'prey-free' control successfully removed $90.8 \%$ of total ciliates, and $92.4 \%$ of small choreotrichs. Ciliate and small choreotrich densities in the 'disturbed' control were, respectively, 66.1 and $66.9 \%$ of those found in the whole-water treatment (Table 2)

Because the uptake of labeled prey by Ceratium furca followed a non-linear pattern after $6 \mathrm{~h}$ of incubation, only the first $6 \mathrm{~h}$ were used to calculate feeding rates. In the whole-water treatment, $C$. furca ingested labeled prey at a rate of $0.097 \pm 0.0096$ prey dinoflagellate ${ }^{-1} \mathrm{~h}^{-1}$ (Fig. 6). C. furca in the 'disturbed' control showed a lower ingestion rate, $0.031 \pm 0.0038$ prey dinoflagellate ${ }^{-1} \mathrm{~h}^{-1}$, and cells in the 'prey-free' control formed very few food vacuoles $(0.001 \pm 0.0009$ prey dinoflagellate $\left.{ }^{-1} \mathrm{~h}^{-1}\right)$. All rates were significantly different from each other $(F=105.54$, df $=2, p<$ $0.0001)$. 
Table 2. Ciliate densities and percentage removed by reverse filtration in 'unscreened', 'prey-free' and 'disturbed' treatments of a time-course feeding experiment with a natural plankton assemblage containing Ceratium furca. Estimates were obtained from QPS preparations of aliquots removed after $1 \mathrm{~h}$ of incubation

\begin{tabular}{|c|c|c|}
\hline & $\begin{array}{l}\text { Cells ml } l^{-1} \\
\quad \pm \mathrm{SE}\end{array}$ & $\begin{array}{l}\text { Percent removed by } \\
\text { reverse filtration }\end{array}$ \\
\hline \multicolumn{3}{|c|}{ Whole-water treatment: } \\
\hline Total & $77.3 \pm 7.15$ & - \\
\hline$\leq 20 \mu \mathrm{m}$ choreotrichs & $67.4 \pm 5.01$ & - \\
\hline \multicolumn{3}{|l|}{ 'Prey-free' control: } \\
\hline Total & $7.1 \pm 0.00$ & 90.8 \\
\hline$\leq 20 \mu \mathrm{m}$ choreotrichs & $5.1 \pm 0.72$ & 92.4 \\
\hline \multicolumn{3}{|l|}{ 'Disturbed' control: } \\
\hline Total & $51.1 \pm 1.53$ & 33.9 \\
\hline$\leq 20 \mu \mathrm{m}$ choreotrichs & $45.1 \pm 2.09$ & 33.1 \\
\hline
\end{tabular}

Characteristics of food vacuole contents and potential prey

Of 208 fluorescently labeled food vacuoles examined for the time-course experiment, 116 contained recognizable food items, Of these, $10.4 \%$ were tintinnids (ingested without lorica), $24.5 \%$ belonged to the genus Strobilidium, and the rest were identifiable only as choreotrich ciliates (Figs $4 \& 5$, Table 3). During the first hour of incubation, $100 \%$ of fluorescently labeled food vacuole contents were recognizable as choreotrich ciliates. This percentage decreased over time, with roughly $50 \%$ of food vacuoles having recognizable prey after $2.5 \mathrm{~h}$. Mean food vacuole diameter was $12.1 \pm$ $0.27 \mu \mathrm{m}$ (median diameter $=11 \mu \mathrm{m}$ ), with a range of 6 to $32 \mu \mathrm{m}$ (Fig. 7A). About $14 \%$ of food vacuoles were smaller than $10 \mu \mathrm{m}$ in diameter, the contents of which were mostly unrecognizable. More than half $(51.5 \%)$ of all food vacuoles and $37.3 \%$ of small $(<10 \mu \mathrm{m})$ food vacuoles contained between 20 and 50 microspheres, with 83.0 and $78.4 \%$ having 10 to 50 microspheres, respectively (Fig. 7B,C). Median sizes of food vacuoles containing various quantities of ingested microspheres were not significantly different from each other (Fig. 7D; $H=7.857, \mathrm{df}=4, \mathrm{p}=0.097$; Kruskal-Wallis 1 -way ANOVA on Ranks). The median size of food vacuoles containing fewer than 10 microspheres $(11 \mu \mathrm{m})$ was also not significantly different from that of food vacuoles with recognizable ciliate contents (12 $\mu \mathrm{m}$; $T=1535.5, p=0.24$; Mann-Whitney Rank Sum Test).

Abundance of potential prey (i.e. protists labeled with fluorescent microspheres) in the whole-water treatment was $822.1 \pm 9.91 \mathrm{ml}^{-1}$. Flagellates, amoebae, ebriids, dinoflagellates and ciliates comprised 82.9 , $0.8,0.9,6.1$, and $9.4 \%$ of total potential prey numbers, respectively. Size distribution of potential prey taxa

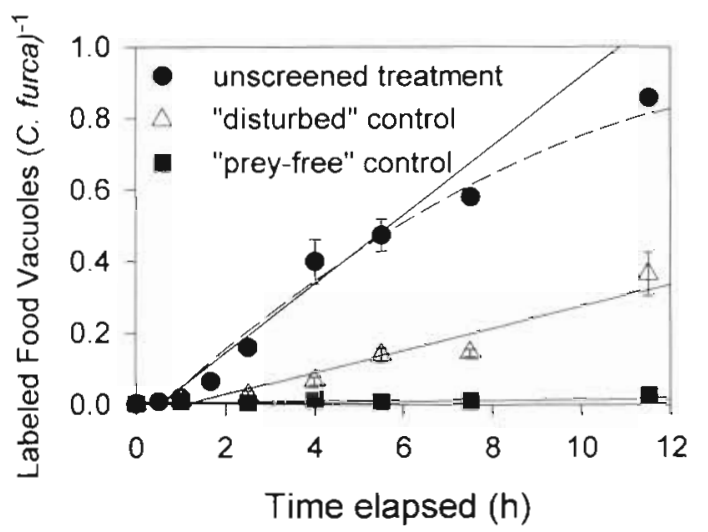

Fig. 6. Ceratium furca. Estimates for ingestion rates obtained during a time-course study using fluorescent microspheres. Ingestion rates were determined as the slope for linear regression (solid lines) of number of labeled food vacuoles per C. furca plotted against time. Only data from the first $6 \mathrm{~h}$ were used to calculate rates. Data plotted as mean \pm SE. Broken line represents line of best fit, determined using SigmaPlot curve fitting procedures

showed that the category corresponding to the most frequently encountered size class of food vacuoles $(10$ to $20 \mu \mathrm{m}$ ) was mainly composed of ciliates, dinoflagellates, and ebriids (Fig. 8A). Flagellates dominated the smaller size classes $(<10 \mu \mathrm{m})$ and had a median diameter of $5 \mu \mathrm{m}$. All potential prey greater than $30 \mu \mathrm{m}$ were ciliates, while those between 20 and $30 \mu \mathrm{m}$ were a mixture of ciliates, dinoflagellates, and ebriids. The number of microspheres ingested by organisms varied depending on taxon (Fig. 8B). Small flagellates and dinoflagellates typically ingested few microspheres $(<10)$, while ciliates and ebriids tended to ingest larger numbers $(>10)$.

\section{Assessment of feeding in natural populations of Ceratium furca}

During the summer of 1995,11 of the 18 experiments showed feeding by Ceratium furca, with mean inges-

Table 3. Ceratium furca. Occurrence of recognizable prey in labeled food vacuoles. Specimens were ubtained from aliquots fixed after $30,60,100,150$, and $240 \mathrm{~min}$ of incubation and subsequently stained using modified Protargol staining procedures

\begin{tabular}{|lcccc|}
\hline Time of incubation & $T_{30,60}$ & $T_{100}$ & $T_{150}$ & $T_{240}$ \\
\hline $\begin{array}{c}\text { Total number of labeled } \\
\text { food vacuoles }\end{array}$ & 6 & 15 & 44 & 143 \\
$\begin{array}{l}\% \text { food vacuoles containing } \\
\text { recognizable prey }\end{array}$ & 100 & 73.3 & 52.4 & 46.2 \\
$\begin{array}{l}\% \text { recognizable prey } \\
\text { as choreotrichs }\end{array}$ & 100 & 100 & 100 & 100 \\
\hline
\end{tabular}



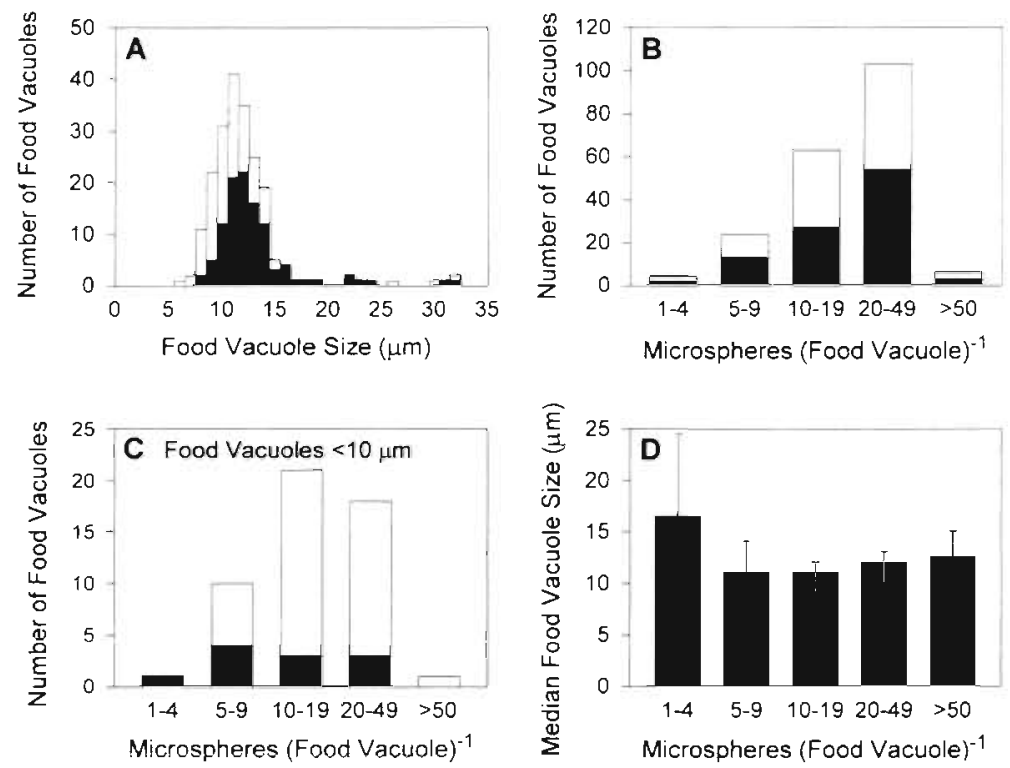

Fig. 7. Ceratium furca. Characteristics of labeled food vacuoles. C. furca specimens were found on quantitative protarged stain (QPS) preparations made from material incubated with $10^{7}$ microspheres $\mathrm{ml}^{-1}$ for 1 to $240 \mathrm{~min}$. Data from all time points were combined. (A) Size distribution of food vacuoles; (B) number of fluorescent microspheres per food vacuole; (C) number of fuorescent microspheres per food vacuole $<10 \mu \mathrm{m}$ in diameter (sample size $=51$ ); (D) median food vacuole size as a function of number of microspheres contained, error bars represent 25 and $75 \%$ percentiles, Food vacuole contents identified as ciliates; $\square$ contents not recognizable. Sample size $=208$ unless other-wise indicated
Clearance rates were highest at low Strobilidium spp. densities and decreased as prey concentrations increased (Fig. 10).

\section{DISCUSSION}

Analysis of food vacuole contents revealed a clear preference by Ceratium furca for small (10 to $40 \mu \mathrm{m}$ ) ciliates, with all identifiable species belonging to the order Choreotrichida (i.e. Strobilidium spp, and tintinnids). Flagellates, amoebae, ebriids, other dinoflagellates, and diatoms were present at high densities during experiments, but were never detected in any $C$. furca food vacuoles. Although many vacuoles contained food items that were not recognizable, comparison of rood vacuole size and number of microspheres per vacuole to the size and microsphere number of potential prey supported the conclusion that the unrecognizable food items represented ciliates at various stages of digestion. Specifically, potential prey taxa within the size range encountered for food vacuoles (6 to $32 \mu \mathrm{m}$ ) included mainly ciliates, dinoflagellates, and ebriids. Ebriids could be ruled out as prey because they, like diatoms, possess siliceous skeletal elements that remain undigested and clearly visible in protistan food vacuoles. Comparing the number of microspheres in food vacuoles to that in potential prey excluded digested dinoflagellates as unrecognizable food items, because most food vacuoles contained between 10 and tion rate for all 18 experiments being $0.006 \pm 0.0046$ prey dinoflagellate ${ }^{-1} \mathrm{~h}^{-1}$ (Table 4). Average ingestion rate excluding cases where no feeding was detected was $0.010 \pm 0.0072$ prey dinoflagellate ${ }^{-1} \mathrm{~h}^{-1}$. Both fre quency of experiments with feeding events $(90.9 \%)$ and mean ingestion rate $(0.025 \pm 0.0056$ prey dinoflagellate ${ }^{-1} \mathrm{~h}^{-1}$, including cases where no feeding was detected; $0.054 \pm$ 0.0058 prey dinoflagellate ${ }^{-1} \mathrm{~h}^{-1}$, excluding those cases) were higher during the summer of 1996. Average ciliate abundance was $29.3 \pm 5.09 \mathrm{ml}^{-1}$ in 1995 and $70.3 \pm 6.38 \mathrm{ml}^{-1}$ in 1996 Feeding rate of $C$. furca expressed as a function of total ciliate or choreotrich abundance showed a significant correlation (total ciliates: $r=0.532, p=$ 0.002 ; choreotrichs: $r=0.481, p=$ 0.005 ; Fig. 9). The correlation coefficient increased markedly when only abundance of Strobilidium spp. was considered $(r=0.836, p<0.0001)$. Clearance rates ranged from 0 to $12.49 \mu \mathrm{h} \mathrm{h}^{-1}$, with an average of $2.1 \pm$ $0.41 \mu \mathrm{l} \mathrm{h} \mathrm{h}^{-1}$ for all 30 experiments.
Table 4. Ceratium furca. In situ feeding experiments conducted during the summer of 1995 and 1996. Ingestion rates were determined by following uptake of prey labeled with fluorescent microspheres. Clearance rates were calculated assuming feeding on Strobilidium spp. only. Ciliate densities were estimated from QPS preparation of aliquots removed after $1 \mathrm{~h}$ of incubation. Sample size $=30$

\begin{tabular}{|lcc|}
\hline Year. & 1995 & 1996 \\
\hline $\begin{array}{l}\text { Number of experiments with: } \\
\quad \text { No feeding }(\%)\end{array}$ & $7(38.9)$ & $2(9.1)$ \\
$\quad$ Feeding $(\%)$ & $11(61.1)$ & $20(90.9)$ \\
Mean ingestion rate (prey C. furca $\left.{ }^{-1} \mathrm{~h}^{-1} \pm \mathrm{SE}\right)$ & & \\
$\quad$ Including all experiments & $0.006 \pm 0.0046$ & $0.025 \pm 0.0056$ \\
$\quad$ Excluding experiments where & $0.010 \pm 0.0072$ & $0.054 \pm 0.0058$ \\
$\quad$ no feeding was observed & $1.91 \pm 0.746$ & $2.20 \pm 0.469$ \\
Mean clearance rate $\left(\mu \mathrm{l} \mathrm{C.} \mathrm{furca}{ }^{-1} \mathrm{~h}^{-1} \pm \mathrm{SE}\right)$ & $29.3 \pm 5.09$ & $70.3 \pm 6.38$ \\
Ciliate density (cells ml $\mathrm{I}^{-1}$ ) & $1.68 \pm 0.432$ & $10.22 \pm 2.183$ \\
Strobilidium spp. density (cells $\mathrm{ml}^{-1}$ ) & & \\
\hline
\end{tabular}




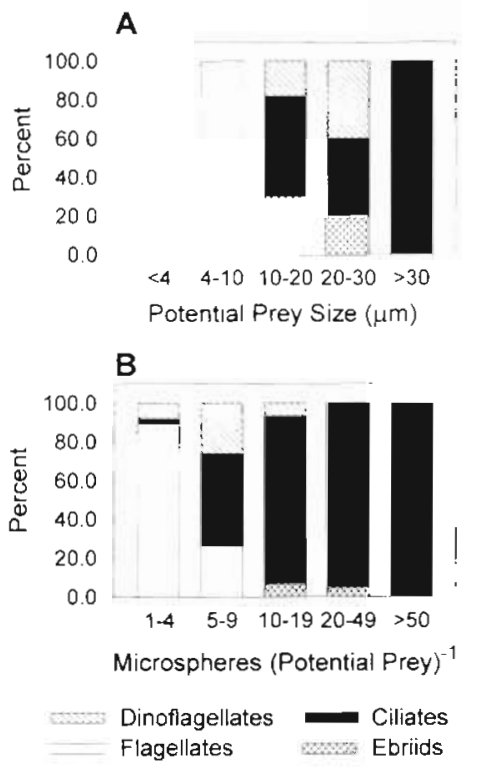

Fig. 8. Characteristics of potential prey. (A) Potential prey taxa expressed as percentage of total potential prey within a particular size range; (B) percentage distribution of potential prey taxa for various ranges of microspheres ingested. Samples were incubated with $10^{7}$ microspheres $\mathrm{ml}^{-1}$ for $60 \mathrm{~min}$ and subsequently stained using modified Protargol procedures

50 microspheres, corresponding to numbers most frequently encountered in ciliates. A small percentage $(5.8 \%)$ of unrecognizable food items contained fewer than 10 microspheres, corresponding to a potential prey category dominated by small flagellates. However, the median diameter of these food vacuoles $(11 \mu \mathrm{m})$ was significantly larger than the median size of flagellates ( $5 \mu \mathrm{m} ; \mathrm{T}=3318, \mathrm{p}<0.001$; Mann-Whitney Rank Sum Test, SigmaStat). In addition, food vacuoles containing unrecognizable prey with fewer than 10 microspheres were not significantly different in size from vacuoles containing labeled ciliates. Finally, approximately $14 \%$ of the food vacuoles were smaller than $10 \mu \mathrm{m}$ in diameter, the contents of which were mostly unrecognizable. These vacuoles could have contained flagellates, which dominated the smallest size class of potential prey. However, this is unlikely

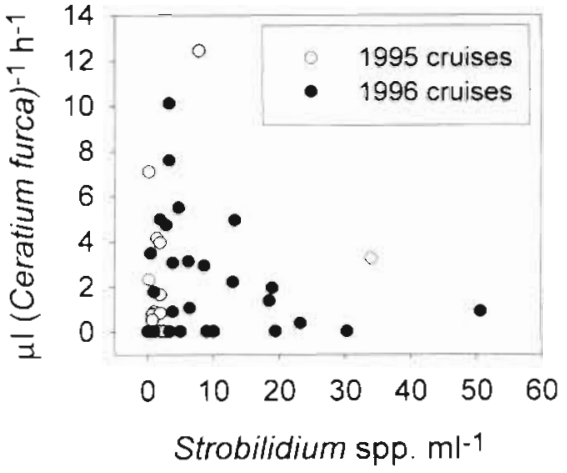

Fig. 10. Ceratium furca. Clearance rates plotted as a function of Strobilidium spp. concentration. Ciliate densities were estimated from QPS preparation of aliquots removed after $1 \mathrm{~h}$ of incubation. Clearance rates were calculated using Strobilidium spp. densities only

because most $(78.4 \%)$ of the less than $10 \mu \mathrm{m}$ food vacuoles contained more than 10 microspheres, while flagellates typically ingested fewer than 10 . Therefore, the less than $10 \mu \mathrm{m}$ vacuoles probably represented ingested ciliate prey at a late stage of digestion.

Ceratium furca formed labeled food vacuoles at an extremely low rate in the 'prey-free' control, raising the possibility that some microspheres may have been ingested directly. However, reverse filtration procedures used to generate the 'prey-free' control only removed $90.8 \%$ of the ciliate population, with the residual prey probably accounting for labeled food vacuoles observed in this treatment. Ingestion rate in the 'disturbed' control was significantly higher than in the 'prey-free' control, indicating that reverse filtration did not prevent $C$. furca from feeding. Therefore, the feeding rate obtained in the whole-water treatment reflects ingestion of labeled prey rather than direct ingestion of microspheres. Although this rate is higher $\left(0.097 \pm 0.0096\right.$ prey $C$. furca $\left.{ }^{-1} \mathrm{~h}^{-1}\right)$ than the average ingestion rate for feeding studies in 1995 and 1996, it falls well within the range obtained for the 2 years $(0$ to 0.11 prey $C$. furca ${ }^{-1} \mathrm{~h}^{-1}$ ) and probably reflects the high choreotrich density during the time-course feeding experiment.
Fig. 9. Ceratium furca. Correlation of ingestion rate by $C$. furca with total ciliate, choreotrich, and Strobilidium spp. abundance. Ingestion rates were determined by following uptake of prey labeled with fluorescent microspheres. Ciliate densities were estimated from QPS preparation of aliquots removed after $1 \mathrm{~h}$ of incubation. (o) 1995 cruises, (•) 1996 cruises
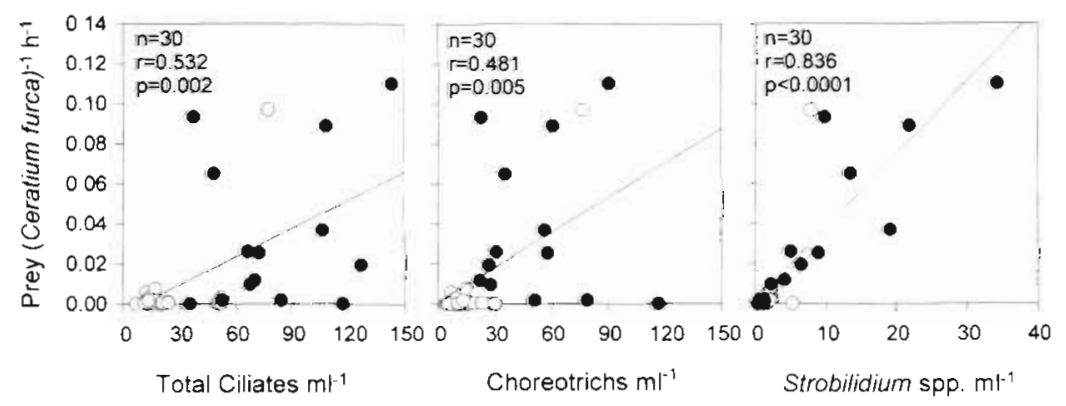
Ingestion of labeled prey by Ceratium furca followed a non-linear pattern and seemed to saturate after $6 \mathrm{~h}$ of incubation (Fig. 6). There are several possible explanations for this apparent saturation. Because the experiment did not start until 13:00 h, only the first 6 or $7 \mathrm{~h}$ of incubation took place during daylight. Reduced irradiance in the evening and at night may have led to a decrease in feeding by $C$. furca, a phenomenon that has been observed for several other dinoflagellates (Skovgaard 1996b, Hansen \& Nielsen 1997, Stoecker et al. 1997). On the other hand, ingestion and defecation of labeled food vacuoles may have reached equilibrium after $6 \mathrm{~h}$, resulting in no net increase of labeled food vacuoles. Both photosynthetic and heterotrophic dinoflagellates are able to produce feces (Buck et al. 1990, Elbrächter 1991), although this process was not observed in our samples. Alternatively, as C. furca was unable to digest latex microspheres, the minimum size of digested vacuoles was limited by the number of microspheres they contained, possibly rendering them too big for defecation. In this case, accumulation of old food vacuoles may have reduced or stopped feeding activities due to space constraints or lack of membrane available for new food vacuole formation. Finally, fusion of labeled food vacuoles over time could have resulted in the observed hyperbolic feeding curve.

Ingestion and clearance rates reported here for Ceratium furca $\left(0\right.$ to 0.11 prey $C$. furca ${ }^{-1} \mathrm{~h}^{-1}$ and 0 to $12.39 \mu \mathrm{l} \mathrm{C}$. furca ${ }^{-1} \mathrm{~h}^{-1}$, respectively) are comparable to rates of other large mixotrophic dinoflagellates. For example, Gymnodinium sanguineum ingested ciliates at a rate of up to 0.06 prey ind.$^{-1} \mathrm{~h}^{-1}$, with clearance rates between 0 and $5.8 \mu \mathrm{l}$ ind $^{-1} \mathrm{~h}^{-1}$ as determined using the 'gut fullness/gut clearance' approach (Bockstahler \& Coats 1993b). In laboratory studies, ingestion and clearance rates of Fragilidium subglobosum reached 0.025 prey ind. ${ }^{-1} \mathrm{~h}^{-1}$ and $3.33 \mu \mathrm{l}$ ind ${ }^{-1} \mathrm{~h}^{-1}$ at highest prey concentrations (Hansen \& Nielsen 1997). Heterotrophic dinoflagellates exhibit a similar range of feeding rates. The small thecate dinoflagellate Oblea rotunda ingested a diatom and a chlorophyte species at 0.05 to 0.15 cells ind ${ }^{-1} \mathrm{~h}^{-1}$ and 0.06 to 1.64 cells ind ${ }^{-1}$ $\mathrm{h}^{-1}$, respectively, with clearance rates on the 2 prey species ranging from 0.08 to $0.24 \mu$ ind $^{-1} \mathrm{~h}^{-1}$ and 0.11 to $0.7 \mathrm{ul}$ ind. ${ }^{-1} \mathrm{~h}^{-1}$ (Strom \& Buskey 1993). Maximum ingestion rates of 2 larger heterotrophic species Protoperidinium cf. divergens and $P$. crassipes feeding on Gonyaulax polyedra were 0.2 and 0.08 prey ind ${ }^{-1} \mathrm{~h}^{-1}$. with clearance rates of 0.67 and $0.47 \mu \mathrm{l}$ ind $^{-1} \mathrm{~h}^{-1}$. respectively (Jeong \& Latz 1994). Lessard \& Swift (1985) reported clearance rates on isotope-labeled prey for several heterotrophic dinoflagellates from the oligotrophic Sargasso Sea, ranging from 0 to $28 \mu \mathrm{l}$ ind. ${ }^{-1} \mathrm{~h}^{-1}$. That ingestion and clearance rates of $C$. furca measured with the technique presented here fall well within ranges reported for other dinoflagellates, suggests close compliance of our method with previously employed techniques. In addition, the decrease in clearance rate with increasing prey concentration observed in this study has been reported for several other dinoflagellates (Bockstahler \& Coats 1993b, Strom \& Buskey 1993, Jeong \& Latz 1994, Hansen \& Nielsen 1997). However, clearance rates were calculated assuming feeding on Strobilidium spp. only. If feeding on other choreotrich taxa is significant, clearance rates reported here could be overestimated by a factor of up to 5 as, on average, Strobilidium spp. represented approximately $20 \%$ of choreotrich abundance.

Correlation analysis of prey abundance and Ceratium furca ingestion rates showed the highest significance when ciliates of the genus Strobilidium were considered. Inclusion of other choreotrich taxa (i.e. tintinnids and oligotrichids) in the analysis resulted in a lower correlation coefficient. These relationships support food vacuole analyses indicating that $C$. furca fed preferentially on Strobilidium spp. In these analy. ses, tintinnids, although recognized in a small percentage of food vacuoles, never represented more than $10 \%$ of the diet of $C$. furca. Preference for certain types of prey has been reported for a variety of dinoflagellates, which seem capable of sorting potential prey not only by size and shape, but also by chemical characteristics (Verity 1991). For example, most Protoperidinium species fed only on diatoms (Jacobson \& Anderson 1986), while the mixotrophic dinoflagellate Fragilidium subglobosum fed exclusively on Ceratium spp. (Skovgaard 1996a). When offered Gymnodinium sanguineum and Gonyaulax polyedra as prey, $P$. cf. divergens preferred $G$. polyedra and produced a pallium much more frequently when these cells were encountered (Jeong \& Latz 1994). Results similar to those found in the present study were reported for $G$. sanguineum, another large mixotrophic dinoflagellate found in Chesapeake Bay that fed primarily on small oligotrichs, but that occasionally ingested diatoms and small dinoflagellates (Bockstahler \& Coats 1993a,b). However, G. sanguineum seemed to prefer nanociliates $(<20 \mu \mathrm{m})$, while $C$. furca was capable of ingesting ciliates of up to $40 \mu \mathrm{m}$ in size. The apparent preference of C. furca for ciliates of the genus Strobilidium, expressed despite an abundance of other potential prey species of similar size and shape, suggests that this mixotroph has chemosensory capabilities. However, swimming behavior of prey may also influence capture success of slow swimming dinoflagellates like $C$. furca. Certain ciliates, including Strobilidium spp., exhibit a unique swimming behavior characterized by long periods of little or no net motion, interrupted by quick jumps. C. furca seems to prefer these species and may 
be better equipped to capture relatively stationary prey.

The mechanism of food uptake by Ceratium furca was not observed in this study. However, the presence of the entire prey, including the cilia, in food vacuoles indicates engulfment rather than pallium-feeding or myzocytosis. Although the latter 2 mechanisms are more common among thecate dinoflagellates (Elbrächter 1991, Schnepf \& Elbrächter 1992), direct engulfment has been suggested for several thecate species. For example, Dodge \& Crawford (1970) and Jacobson \& Andersen (1994) used transmission electron microscopy to demonstrate large intact prey in a variety of peridinoid, gonyaulocoid, and prorocentroid dinoflagellates including Ceratium. Bockstahler \& Coats (1993a) used cytological staining techniques to show whole prey organisms in the food vacuoles of $C$. furca, as well as in 2 non-thecate species, Gymnodinium sanguineum and Gyrodinium uncatenum. Finally, Hofender (1930) described pseudopodial engulfment in $C$. hirundinella, which ingested prey through the large sulcal region, while Skovgaard (1996a) documented the sequence of direct engulfment of Ceratium spp. by Fragilidium subglobosum in a study using light and transmission electron microscopy.

The use of fluorescent microspheres as indirect tracers to detect feeding in Ceratium furca has several advantages over other methods. Unlike most tracer and isotope labeling techniques, our approach requires no pre-filtering or addition of prey. The approach uses natural populations of living prey that are quickly labeled without apparent alteration of swimming behavior or surface properties. Prey remain labeled throughout experiments and direct uptake of prey by predators can be easily and quickly observed and measured using fluorescent microscopy.

However, there are disadvantages to our approach as well. As with most methods, incubation time is limited to several hours. One constraint on the incubation time results from the influence of ingesting latex microspheres on prey growth and survival. Ingestion of microspheres appears to deprive ciliates of nutrition necessary to sustain reproduction, as net growth of labeled ciliate populations slowed or ceased completely compared to that of ciliates in 'microspherefree' controls. Following addition of microspheres, ciliate densities remained stable for 6 to $7 \mathrm{~h}$, after which their numbers and feeding rates of Ceratium furca on labeled prey began to decline. Second, feeding on prey that do not ingest fluorescent microspheres, such as diatoms and certain ciliates and flagellates, cannot be accounted for by this technique. This problem is minimized in the current study, as $C$. furca prefers small choreotrich ciliates, which readily ingest the label. However, we have on occasion observed feeding by $C$. furca and other mixotrophic dinoflagellates on Mesodinium rubrum, a photosynthetic ciliate that remains unlabeled (data not presented). To quantify feeding on this ciliate, other techniques have to be considered in conjunction with the one described here. For example, ingestion of $M$. rubrum by $C$. furca can be detected using the method described by $\mathrm{Li}$ et al. (1996), because the phycoerythrin-containing symbionts of the ciliate exhibit a distinct orange autofluorescence that can be observed with epifluorescent microscopy. Finally, addition of high concentrations of fluorescent microspheres to plankton samples is likely to alter the photic environment by decreasing light penetration and shifting spectral composition. Whether or not such changes in the light intensity and spectral quality influenced our measurements of ingestion rate in C. furca is uncertain, but is of concern as feeding in several mixotrophic protozoa is known to depend on light intensity (Berk et al. 1991, Caron et al. 1993, Skovgaard 1996b, Hansen \& Nielsen 1997).

Mixotrophy in dinoflagellates such as Ceratium furca may play an important role in food web dynamics. Mixotrophic dinoflagellates that consume nanoand microciliate prey may compete directly with copepods and other macrozooplankton for a common food source. Under bloom conditions, these dinoflagellates could exert considerable grazing pressure on certain other protists. Mixotrophy reverses the classically envisioned energy flow from primary producers to consumers. Consequently, predation by large phototrophic dinoflagellates on ciliates may decrease trophic transfer efficiency within the plankton community, as these mixotrophs are not readily ingested by higher trophic levels (Bockstahler \& Coats 1993b). Using the method described here, the influence of mixotrophic dinoflagellates like C. furca, as well as of certain other protists, on food web dynamics can be investigated. This method will also allow us to study other interesting aspects of mixotrophy in C. furca, such as factors influencing feeding or nutritional benefits derived from this feeding strategy.

Acknowledgements. We thank the captain and crew of the RV 'Cape Henlopen' for ship operations and on-deck assistance, and Diane K. Stoecker for discussion of and helpful comments on the experiments and the manuscript. This research was supported by NSF grant OCE931772 awarded to D.W.C. and Diane K. Stoecker and by a Smithsonian Environmental Research Center Internship and Graduate Fellowship awarded to G.W.S.

\section{LITERATURE CITED}

Andersson A, Falk S, Samuelsson G, Hagstrom \& (1989) Nutritional characteristics of a mixotrophic nanoflagellate, Ochromonas sp. Microb Ecol 17:251-262 
Berk SG, Parks LH, Ting RS (1991) Photoadaptation alters the ingestion rate of Paramecium bursaria, a mixotrophic ciliate. Appl Environ Microbiol 57(8):2312-2316

Bird DF, Kalff J (1987) Algal phagotrophy: regulating factors and importance relative to photosynthesis in Dinobryon (Chrysophyceae). Limnol Oceanogr 32:277-284

Bockstahler KR, Coats DW (1993a) Spatial and temporal aspects of mixotrophy in Chesapeake Bay dinoflagellates. J Protozool 40:49-60

Bockstahler KR Coats DW (1993b) Grazing of the mixotrophic dinoflagellate Gymnodinium sanguineum on ciliate populations of Chesapeake Bay. Mar Biol 116:477-487

Buck KR, Bolt PA, Garrison DL (1990) Phagotrophy and fecal pellet production by an athecate dinoflagellate in Antarctic sea ice. Mar Ecol Prog Ser 60:75-84

Cachon M, Cachon J, Cosson J, Greuet C, Huitorel P (1991) Dinoflagellate flagella adopt various conformations in response to different needs. Biol Cell 71:175-182

Caron DA, Sanders RW, Lim EI., Marrasé C, Amaral LA, Whitney S, Aoki RB, Porter KG (1993) Light-dependent phagotrophy in the freshwater mixotrophic chrysophyte Dinobryon cylindricum. Microb Ecol 25:93-111

Chang J, Carpenter EJ (1994) Inclusion bodies in several species of Ceratium Schrank (Dinophyceae) from the Caribbean Sea examined with DNA-specific staining. J Plankton Res 16:197-202

Cleven EJ (1996) Indirectly fluorescently labeled flagellates (IFLF): a tool to estimate the predation on free-living heterotrophic flagellates. J Plankton Res 18(3):429-442

Coats DW, Heinbokel JF (1982) A study of reproduction and other life cycle phenomena in planktonic protists using an acridine orange fluorescence technique. Mar Biol 67: $71-79$

Dodge JD, Crawford RM (1970) The morphology and fine structure of Ceratium hirundinella (Dinophyceae). J Phycol 6:137-149

Dolan JR, Coats DW (1991a) Preliminary prey digestion in a predacious estuarine ciliate, Euplotes woodruffi, and the use of digestion data to estimate ingestion. Limnol Oceanogr 36:558-565

Dolan JR, Coats DW (1991b) A study of feeding in predatious ciliates using prey ciliates labeled with fluorescent microspheres. J Plankton Res 13(3):609-627

Elbrächter M (1991) Faeces production by dinoflagellates and other small flagellates. Mar Microb Food Webs 5(2) 189-204

Hansen PJ, Nielsen TG (1997) Mixotrophic feeding of Fragilidium subglobosum (Dinophyceae) on three species of Ceratium: effects of prey concentration, prey species and light intensity. Mar Ecol Prog Ser 147:187-196

Hofender H (1930) Über die animalische Ernährung von Ceratium hirundinella O. F. Müller und über die Rolle des Kernes bei djeser Zel]funktion. Arch Protistenkd 71:1=32

Jacobson DM, Anderson DM (1986) Thecate heterotrophic dinoflagellates: feeding hehavinr and merhanisms. J Phycol 22:249-258

Jacobson DM, Anderson DM (1994) The discovery of mixotrophy in protosynthetic species of Dinophysis (Dinophyceae): light and electron microscopical observations of food vacuoles in Dinophysis acuminata, D. norvegica and two heterotrophic dinophysoid dinoflagellates. Phycologia $33: 97-110$

Jacobson DM, Anderson DM (1996) Widespread phagocytosis of ciliates and other protists by marine mixotrophic and heterotrophic thecate dinoflagellates. J Phycol 32:279-285

Jeong HJ, Latz MI (1994) Growth and grazing rates of the heterotrophic dinoflagellates Protoperidinium spp. on red tide dinoflagellates. Mar Ecol. Prog Ser 106:173-185

Jones HLJ, Leadbeater BSC, Green JC (1993) Mixotrophy in marine species of Chrysochromulina (Prymnesiophyceae) ingestion and digestion of a small green flagellate. J Mar Biol Assoc UK 73:283-296

Jones RI (1994) Mixotrophy in planktonic protists as a spectrum of nutritional strategies. Mar Microb Food Webs 8 $87-96$

Kopylov AI, Tumantseva NI (1987) Analysis of the contents of tintinnid food vacuoles and evaluation of their contribution to the consumption of phytoplankton production off the Peru coast. Oceanology 27:343-347

Landry MR (1994) Methods and controls for measuring the grazing impact of planktonic protists. Mar Microb Food Webs $8(1-2): 37-57$

Lessard EJ, Swift E (1985) Species-specific grazing rates of heterotrophic dinoflagellates in oceanic waters, measured with dual-label radioisotope technique. Mar Biol 87: 289-296

Li A, Stoecker DK, Coats DW, Adam JE (1996) Ingestion of fluorescently labeled and phycoerythrin-containing prey by mixotrophic dinoflagellates. Aquat Microb Ecol 10: $139-147$

Marshall HG (1980) Seasonal phytoplankton composition in the lower Chesapeake Bay and Old Plantation Creek, Cape Charles, Virginia. Estuaries 3:207-216

McManus GB, Fuhrman JA (1985) Bacterivory in seawater studied with the use of inert fluorescent particles. Limnol Oceanogr 31(2):420-426

Montagnes DJ, Lynn DH (1987) A quantitative protargol stain (QPS) for ciliates: method description and test of its quantitative nature. Mar Microb Food Webs 2:83-93

Mulford RA (1963) Distribution of the dinoflagellate genus Ceratium in the tidal and offshore waters of Virginia. Chesapeake Sci 4:84-89

Norris DR (1969) Possible phagotrophic feeding in Ceratium lunula Schimper. Limnol Oceanogr 14:448-449

Nygaard K, Hessen O (1990) Use of ${ }^{14} \mathrm{C}$-protein-labeled bacteria for estimating clearance rates by heterotrophic and mixotrophic flagellates. Mar Ecol Prog Ser 68:7-14

Nygaard K, Tobiesen A (1993) Bacterivory in algae: a survival strategy during nutrient limitation. Limnol Oceanogr $38(2): 273-279$

Rothhaupt KO (1996) Laboratory experiments with a mixotrophic chrysophyte and obligately phagotrophic and phototrophic competitors. Ecology 73:716-724

Rublee PA, Gallegos CL (1989) Use of fluorescently labeled algae (FLA) to estimate microzooplankton grazing. Mar Ecol Prog Ser 51:221-227

Sanders RW (1991) Mixotrophic protists in marine and freshwater ecosystems. J Protozool 38:76-81

Sanders RW, Porter KG, Caron DA (1990) Relationship between phototrophy and phagotrophy in the mixotrophic chrysophyte Proterioochromonas malhamensis. Microb Ecol 19:97-109

SAS (1996) The SAS system for Windows, release 6.12. SAS Institute Inc, Cary, NC

Schnepf EM, Elbrächter M (1992) Nutritional strategies in dinoflagellates. Eur J Protistol 28:3-24

Sherr BF, Sherr EB, Fallon RD (1987) Use of monodispersed, fluorescently-labeled bacteria to estimate in situ protozoan bacterivory. Appl Environ Microbiol 53:958-965

Sherr BF, Sherr EB, McDaniel J (1991) Clearance rates of $<6 \mu \mathrm{m}$ fluorescently labeled algae (FLA) by estuarine protozoa: potential grazing impact of flagellates and ciliates. Mar Ecol Prog Ser 69:81-92

Skovgaard A (1996a) Engulfment of Ceratium spp. (Dino- 
phyceae) by the thecate photosynthetic dinoflagellate Fragilidium subglobosum. Phycologia 35(6):490-499

Skovgaard A (1996b) Mixotrophy in Fragilidium subglobosum (Dinophyceae): growth and grazing responses as functions of light intensity. Mar Ecol Prog Ser 143:247-253

Stoecker DK (1988) Are marine planktonic ciliates suspension feeders? J Protozool 35:252-255

Stoecker DK, Li A, Coats DW, Gustafson DE, Nannen MK

Editorial responsibility: Robert Sanders,

Philadelphia, Pennsylvania, USA
(1997) Mixotrophy in the dinoflagellate Prorocentrum minimum. Mar Ecol Prog Ser 152:1-12

Strom SL, Buskey EJ (1993) Feeding, growth and behavior of the thecate heterotrophic dinoflagellate Oblea rotunda. Limnol Oceanogr 38(5):965-977

Verity P (1991) Feeding in planktonic protozoans: evidence for non-random acquisition of prey. J Protozool 38(1): $69-76$

Submitted: June 30,1998; Accepted: September 18, 1998 Proofs received from author(s): May 10, 1999 